1978

\title{
Richard Fishacre's Quaestio on the Ascension of Christ: An Edition
}

\author{
R. James Long \\ Fairfield University, rjlong@fairfield.edu
}

Follow this and additional works at: https://digitalcommons.fairfield.edu/philosophy-facultypubs Copyright 1978 Pontifical Institute of Mediaeval Studies

\section{Peer Reviewed}

\section{Repository Citation}

Long, R. James, "Richard Fishacre's Quaestio on the Ascension of Christ: An Edition" (1978). Philosophy Faculty Publications. 16.

https://digitalcommons.fairfield.edu/philosophy-facultypubs/16

\section{Published Citation}

Long, R. James (1978). "Richard Fishacre's Quaestio on the Ascension of Christ: An Edition," Mediaeval Studies 40 (1978) 3055.

This item has been accepted for inclusion in DigitalCommons@Fairfield by an authorized administrator of DigitalCommons@Fairfield. It is brought to you by DigitalCommons@Fairfield with permission from the rightsholder(s) and is protected by copyright and/or related rights. You are free to use this item in any way that is permitted by the copyright and related rights legislation that applies to your use. For other uses, you need to obtain permission from the rights-holder(s) directly, unless additional rights are indicated by a Creative Commons license in the record and/or on the work itself. For more information, please contact digitalcommons@fairfield.edu. 


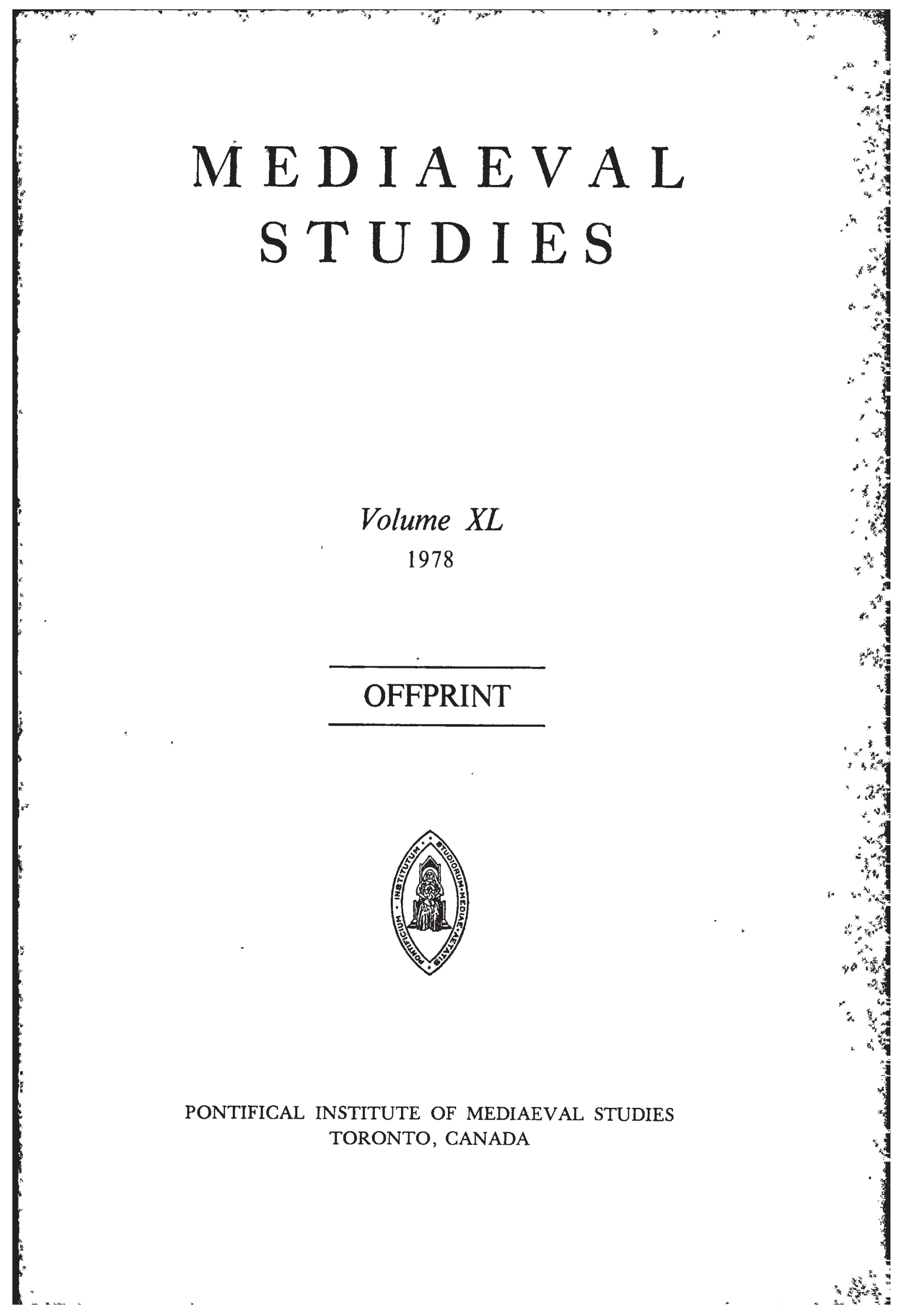




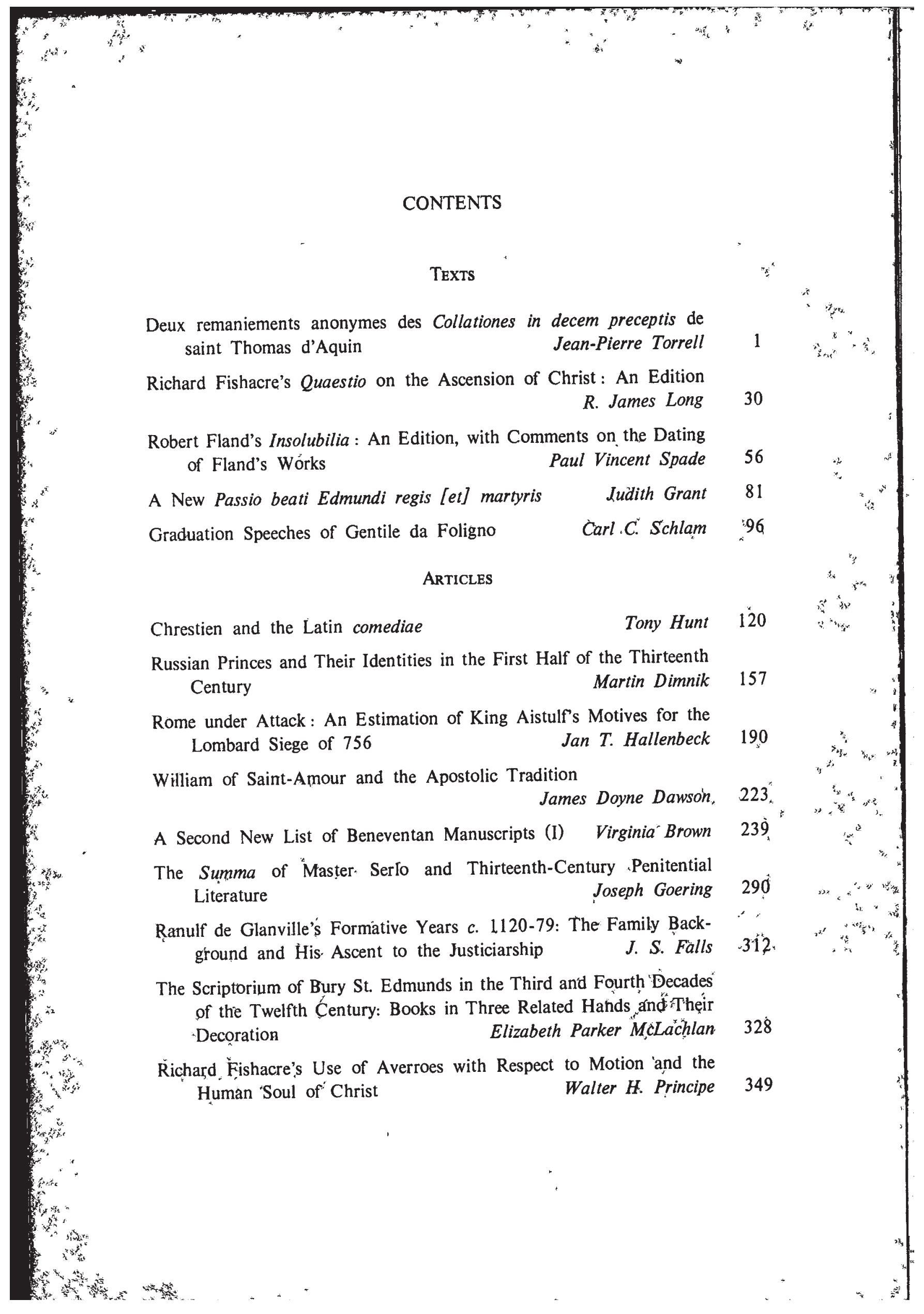




\title{
RICHARD FISHACRE'S QUAESTIO ON THE ASCENSION OF CHRIST : AN EDITION
}

\author{
R. James Long
}

ThAT the-studium at Oxford from the beginning exhibited a distinctly scientific 1 orientation is a fact well established by historians of medieval thought. ${ }^{1}$ This interest in the positive sciences, moreover, was true both of the seculars (like Alfred of Sareshel, Daniel of Morley, John Blund, and Robert Grosseteste) and also the Franciscans (like Adam Marsh, Richard Rufus, and Roger Bacon), the latter group owing their interest at least in part to the tutelage of Grosseteste.

What is not so well established is the intellectual identity of the early Dominicans at Oxford. Did they share the scientific interests of their colleagues or did they incline more toward the speculative interests of the Paris theologians? Here the sources are scanty. Aside from a commentary on the Psalms and a few sermons by his mentor Robert Bacon, ${ }^{2}$ the works of Richard Fishacre provide the sole surviving witness for the teaching activities of the early English Dominicans. $^{3}$

In the Prologue to his Sentence-Commentary, which was probably the first composed at Oxford, ${ }^{4}$ Fishacre articulates the commonplace rationale for the

I See especially D. A. Callus, "Introduction of Aristotelian Learning to Oxford", Proceedings of the British Academy 29 (1943) 3-55.

2 MS. Bodley 745 (2764), fols. 193-497; and British Library MS. Royal 7.A.ix, fol. 70v. See 'B. Smalley, 'Robert Bacon and the Early Dominican School at Oxford', Transactions of the Royat "Historical, Society 30 (1948) 3-16.

3 Fishacre's extant works include a Sentence-Commentary (which survives in eleven MSS.), a treatise on heresies, the quaestio on the Ascension of Christ edited here, a collection of seventy-two quaestiones excerpted from the Sentence-Commentary (in Cambridge, Trinity Coll. MS. 0.1.30), a number of sermons (see e.g. Cambridge, Trinity Coll. MS. B.15.38, fols. 24r-33r), and a treatise entitled $\mathrm{De}$ fide, spe, et caritate (which is possibly the anonymous piece by the same title in $\mathrm{Ox}$ ford. Corpus Christi Coll. MS. 32, fols. 59r-63v: see L. E. Boyle. "Three English Pastoral Sum† mae and a "Magister Galienus". Studia Gratiana 11 [1967] 140 n. 15).

4 Callus, 'Aristotelian Learning', 32; and R. J. Long, "The Science of Theology according to Richard Fishacre: Edition of the Prologue to His Commentary on the Sentences', Mediaeval Studies 34 (1972) 71 n. 1. 
study of the sciences, namely as a propaedeutic to the study of Sacred Scripture. ${ }^{5}$ $\mathrm{He}$ finds a figure for this ancillary relationship in the Old Testament tale of Abraham, who had first to sleep with the maidservant Agar before his wife Sarah could 'conceive, the former representing the sciences, the latter theology. ${ }^{6}$ Although he endorses such a relationship, Fishacre warns of the risks involved. There were those in his day, he admits with astonishment ('fateor mirabile'), who delighted solely in the embraces of a common handmaid and cared nothing for the lady of the house, though possessed of incomparable beauty. When they finally tore themselves away from the bosom of the sêcular sciences, moreover, they found themselves to be impotent with the queen of the sciences owing, to their advanced age, just as David in his declining years bedded the beautiful Abisag for her warmth but did not know her carnally.'

This approach to theology via the secular sciences is admirably illustrated in an untitled and anonymous 'quaestio on the Ascension of Christ which occurs at the end of Vatican MS. Ottob. lat. 294. On the evidence both external and internal, which I will review below, I feel confident in ascribing the piece to Fishacre. If his Sentence-Commentary can be dated circa $1241-45,{ }^{8}$ I would tentatively place the De ascensione between 1245 and 1248, the year of Fishacre's death. 'The style, the rather unfinished nature of the text, and especially the character of the rather frequent errors, moreover, all suggest strongly that the original was in the form of a reportatio. ${ }^{9}$

The first and most obvious argument for the authorship of the work is its physical location, namely, appended to a copy of Fishacre's SentenceCommentary. ${ }^{10}$ The scribe of the De ascensione, furthermore, was one of several who labored over the latter. More significantly, the style of the piece, principally its cautious, tone, is unmistakably Fishacręs. Like many an untenured fąculty member he tends to abstain on issues that reflect a division of opinion. In the Sentence-Commentary this hesitancy saves him from committing himself on such sensitive and complex questions as the plurality of forms. "In the De ascensione

5 'Hinc insuper patet quod accedentem ad hanc < theologiam> oportet alias < scientias $>$ praecognoscere vel universaliter omnes vel pro magna parte; alioquin ignorabit exempla huius scientiae' (Long, ibid., 85).

6 ibid., 85-86.

7 ibid., 86-87.

8 ibid., 74.

9 There are a number of stylistic clues that would indicate that the piece resulted from the reciprocity of live debate and the reporting thereof: e.g. dicebat (p. 46), ad hoc quod dicis (p. 47). cuius des subtilitatem (p. 50), responde (p. 54). The textual corruptions, moreover, that are likely to have resulted from oral transmission are noted in the apparatus.

.10 The codex contains as well adnotationes on Augustine's De haeresibus (fols. 287r-294v), which I would argue on similar grounds are from the pen of Richard Fishacre.

11 R. J. Long. 'Richard Fishacre and the Problem of the Soul', The Modern Schoolman 52 (1975) $265-66$. 


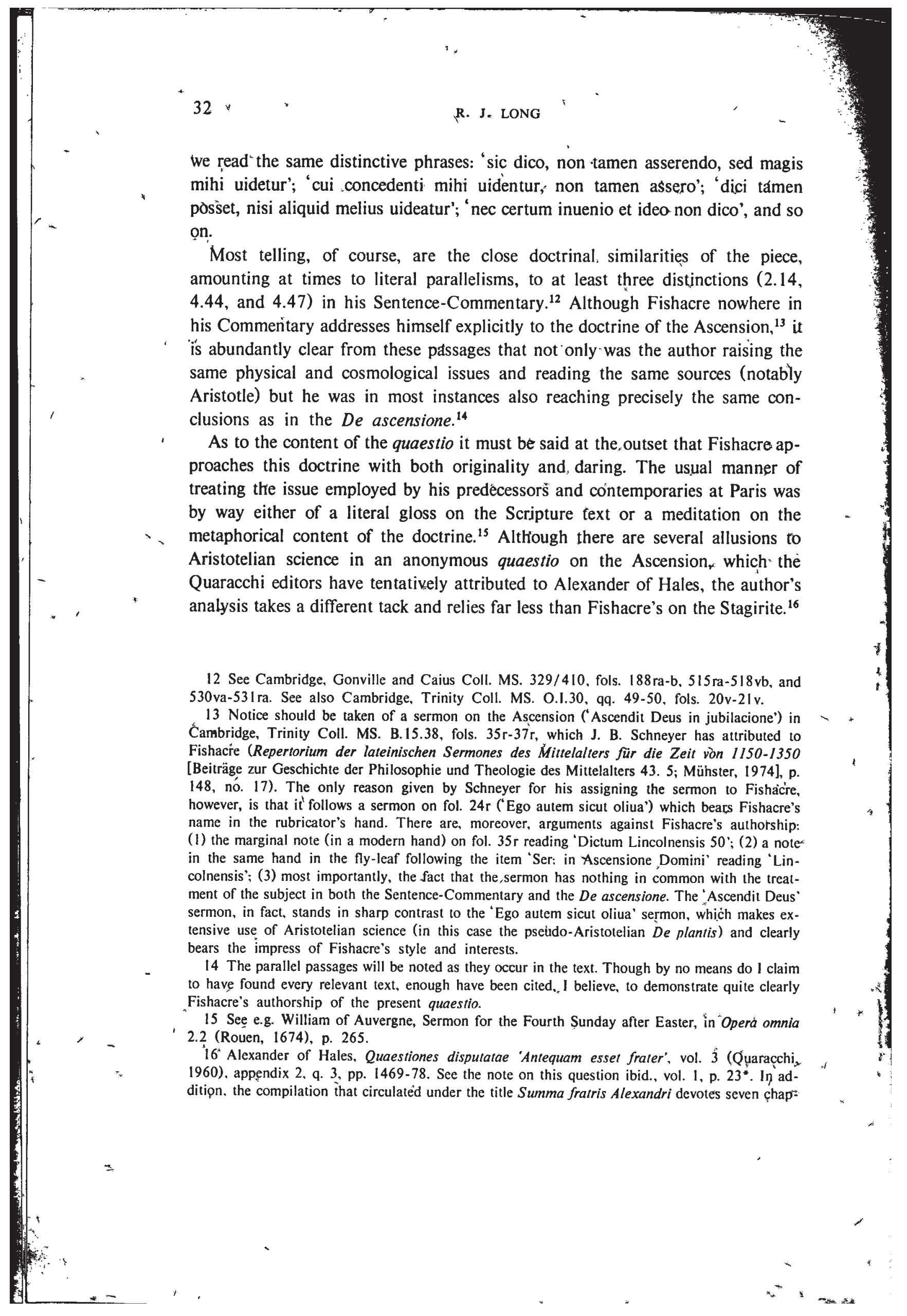


Since the-Lombard did not include the doctrine in his Sentences, it was not in\& cumbent on his commentators to raise the issue. Neither Alexander's Glosses on the Sentences, a prototype of such works at Paris, nor Fishacre's Commentary, as :mentioned, contain any specific treatment of Christ's ascension. However, when Peter Lombard asks about the nature and location of Christ during the three days between his crucifixion and resurrection (3.22), Thomas Aquinas finds occasion also to ask several questions about his ascension: namely "whether Christ ought to have ascended?'; "whether the motion of the Ascension was forced (violentus)?'; and finally, 'whether Christ ascended above the heavens?'17

Until Aquinias' careful and thorough discussion of the question, however, Fishacre's opuscule stands virtually alone with respect to the extent to which he makes use of the new science. ${ }^{18}$ Invoking the Aristotelian concepts of natural place, natural motion, gravity and levity, vacuum, and time, Fishacre asks by what power Christ's ascension took place, that is, was it by virtue of his divinity, his soul, or his body? That it was possible that Chirist ascended by virtue of his

i divinity, Fishacre establishes by citing the authority of Scripture. The possibility of the Ascension taking place by the power of Christ's soul, however, merits a lengthier discussion. Four arguments are advanced, all to the effect that the rational soul is deserving of the highest place in the universe because it is the noblest of creatures; furthermore, it will naturally be conveyed to that place unless impeded. ${ }^{19}$

Does not the glorified body impede the soul, asks Fishacre? Decidedly not, is his response, and he formulates no less than nine arguments to prove it. Most of these arguments are a fortiori and offer little difficulty of interpretation. The third, for example, runs as follows: a sound albeit heavy body is more mobile

ters to the Ascension (Alexander of Hales. Summa theologica III, tr. 7, q. 1; vol. 4 [Qùaracchi, 1948]. pp.-278-92). Despite the occasional reference to Aristotle and two citations of St. Augustine "in common with Fishacre, there is no evidence to suggest that the one work influenced the other, Since, moreover, a version of the Summa was in circulation about 1250, the dates of composition/compilation for the two works are roughly contemporaneous.

173 Sent. 22.3.1-3 (Parma, 7.232-35).

18 My examination of the works of Fishacre's contemporaries has admittedly not been exhaustive. Mention should be made, for example, of two anonymous questions (one possibly Alexandrine) on the Ascension in Prague, Univ. MS. IV.D.13, fols. $211 \mathrm{vb}-213 \mathrm{va}$ (described by B.-G. Guyot, "Quaestiones Guerrici, Alexandri et aliorum magistrorum Parisiensium', Archivum Fratrum Praedicatorum 32 [1962] 86). The second was printed by the Quaracchi editors as Alexandrine material (see n. 16 above), but the first (listęd as no. 216) seems to contain, according to Guyot's summary description, à scientific analysis not unlike Fishacre's. Also Guerric of SaintQuèntin has a question on the Ascension in Todi, Biblioteca Comunale MS. 71, fols. 59c-60b. which I have not had the opportunity to examine.

19 See below, pp. 43-44. A version of this commentary was read at the Eleventh Annual Con'ference 'on Medieval Studies, Kalamazoo, Michigan. May 1976. 
than a light and infirm body (according to the authority of St. Auguistine); but since Christ's soul is most robust, his body is perfectly sound; therefore, most mobile. In the seventh argument he asks rhetorically why, if by virtue of a, heavenly body water is suspended in clouds (above its natural sphere), cannot the glorified body, which is lighter than water, be raised on high by the power of the spirit, which is heavenly by nature; or similarly (in the ninth argument), if the spirits of birds can keep their non-glorified bodies in the airy sphere, why cannot the soul of Christ bear his lighter body (because glorified) into the empyrean, the highest sphere of heaven ${ }^{20}$

To the thesis that the soul by its very nature ascends Fishacre presents two objections. First, it would seem that the souls of the damned descend into hell. Do they do so willingly, forcedly, or naturally? Eliminating the first two alternatives, it remains that certain souls descend of their own nature. Secondly, if the natural appetite of the angel is to be in heaven, its beatitude is diminished whenever it is sent thence on a divine mission; the implication is that this is unseemly. ${ }^{21}$

Fishacre resolves the difficulty by drawing a distinction; a place is said to be natural to a thing in two ways: (1) because the substance in question has a natural form by which it is inclined toward and desires that place (such being the case with the elements), and (2) because it has a natural form by which it desires that which is suitable to its nature (for example, the bird that is drawn to its nest but leaves it temporarily in search of food). The latter is the case with the - rational spirit, which by its specific form desires naturally whatever it sees as being in harmony with its nature, including the highest place, the empyrean heaven. ${ }^{22}$

Replying to the first objection regarding the souls of the damned, the Dominican distinguishes four ways in which a substance can be in a place: naturally and not voluntarily (for example, heavy bodies), voluntarily and not naturally (for example, angels when they are heré below), naturally and voluntarily (for example, the blessed spirits in heaven), and lastly, neither naturally nor voluntarily. It is to this last category that the souls of the damned belong. However, by what power they are retained there (since they are there only by force), Fishacre does not know, suggesting only that it may be the same power that suspends water in clouds, that is, above their natural place. Alternatively Fishacre also hesitates to assert this - there may be a bonding between the damned spirits and the fires of hell, which is yet not altogether like the composition of body and soul in man. Thus it would be divine power that effects the bond and by the latter would they be forcibly detained. ${ }^{23}$.

20 pp. $44-45$.

21 pp. $45-46$.

22 p. 46.

23 pp. $46-47$. 
Responding to the sècond objection, that the beatitude of the angels is". diminished when they are apart from their natural place, Fishacre posits a distinction between grace and nature. In the angels the latter is ennobled and as it were absorbed in its entirety by the former. Therefore, they delight more in the works of grace (for example, coming here below in response to the divine will) than in remaining in heaven in accordance with their nature. Nor is this contrary to their nature. There are indeed in the angels not contrary appetites but appetites for two things that are not compossible (that is, to be in heaven and here below at the same time). But the one appetite belongs to nature, the other to the informed will. ${ }^{24}$

Resuming his original division of the text, Fishacre raises the third possibility, namely, that it is solely by virtue of his glorified body that Christ could have ascended. In support of this option the Oxonian marshals thirteen arguments, punctuated occasionally by objections to which he then immediately replies. To the nobler body, runs the first argument, belongs the higher place; but the body of Christ is noblest; therefore, and so on. ${ }^{25}$

According to this line of reasoning, one objects, the sun would be higher than all the stars (on the Aristotelian supposition that the sun is nobler). As a consequence of this absurd situation, the empyrean, that-sphere of the heavens above the stellar sphere, would be occupied by a body, namely, the sun, and there would then be no room there for the body of Christ. ${ }^{26}$

He answers the objection by. affirming the truth of his original proposition with respect to those heavenly bodies whose sole function is ornamental; it may be the case, however, that the proper working of the universe as a whole should dictate a different arrangement. Perhaps, he suggests, the sun is endowed by nature with a greater appetite for a locus medius than for the supreme poșition to which its nobility entitles it. The objection in any case is clearly not relevant to the body of Christ. ${ }^{27}$

His second argument is that the heavens were made for man, including his body, and according to Sacred Scripture are in his service. But this servitude

24 To illustrate this distinction he cites the example of Christ's agony before his death. The meaning seems to be that the two appetites are not divided against themselves, just as Christ's flesh, which willed not to die, did not in fact desire anything in opposition to the spirit (which willed the death of the body), 'because the spirit willed that the flesh should so will'. Or, Fishacre continues, it could be said that just as the deity, which has power over the humanity in Christ, permits it sometimes to sleep. to suffer, and in general to perform human acts, so also the informed will enjoys such sovereignty over the nature joined to it that it can temporarily disallow the functioning of its proper act (e.g. that it actually desire. rather than avoid, the wood of the cross). Such an act is not contrary to nature, but above it (pp. 47-48).

25 p. 48.

26 ibid.

27 ibid. 
should extend even to physical location. Therefore, man's natural position is above the heavenly bodies. ${ }^{28}$

His third argument is particularly obtuse: Heaven ${ }_{\text {is }}$ the natural dwelling place of the soul. Some souls, however, are brought there by violent means, ${ }^{29}$ since man is capable of killing himself. Is it not reasonable to suppose, Fishacre asks, that the earthly substance can dwell in heaven naturally (in opposition to* 'violently') and also move there naturally ? ${ }^{30}$

Fourthly, there is a greater difference between spirit"and body than between one body and another. But the spirit dwells in the body naturally. Therefore, $a$ fortiori à body should be able to inhabit another body - specifically the glorified body should be capable of dwelling in the celestial body. ${ }^{31}$

To these last arguments the following objection is raised. If the natural place of the entire earth is the same as for that of a sirtgle clod, and if the clod of earth. which is the body of Christ is naturally on high, so too will be the entire earth at least when it will have been glorified. ${ }^{32 s}$

Fishacre responds by stating that the proposition (which is, in fact, Aristotle's) is true only of a clod or atom of earth not united to another and especially to a nobler nature (as is the case with earth in the body of Christ). Also in the glorified human body the weight of the earthly element will" be removed, which may not be true of the entire glorified earth - in which case their place will.not be the same. ${ }^{33}$

The following eight arguments pròceed in similar fashion and cause no particular difficulty. The thirteenth argument (in support of the Ascension taking place by virtue of the body) is, however, somewhat convoluted. Fishacre establishes first that the universe consists of four concentric spheres: earth, air, the stellar heaven, and the empyrean. The phrase 'heaven and earth' is frequently used by the sacred writers to signify every creature, ${ }^{34}$ for 'heaven' is three-tiered (airr, stars, and the empyrean). There is, moreover, a hierarchy among the bodies that adorn the universe, the opaque being the less noble, the luminous the more

28 pp. $48-49$.

29 Literally 'this violence someone inflicts on it (i.e. the soul)'; I 'suspect the text -is corrupt here, the original positing the opposition' between anima/infernum/violencia and corpus/celum/natura. Thus, "if the soul can be borne to hell by violent means (i.e. suicide), a fortiori the body can be borne to heaven by natural means'. This is merely a conjecture, and I have found no parallel text in the Sentence-Commentary to support it

30 p. 49

31 ibid.

32 ibid.

33 ibid.

34 In the Pentateuch alone see e.g. Gen I:1, 2:1, 2:4, 14:19, 14:22, 24:3; Ex 20:11, 31:17;
Deut $4: 26,30: 19,31: 28$. 


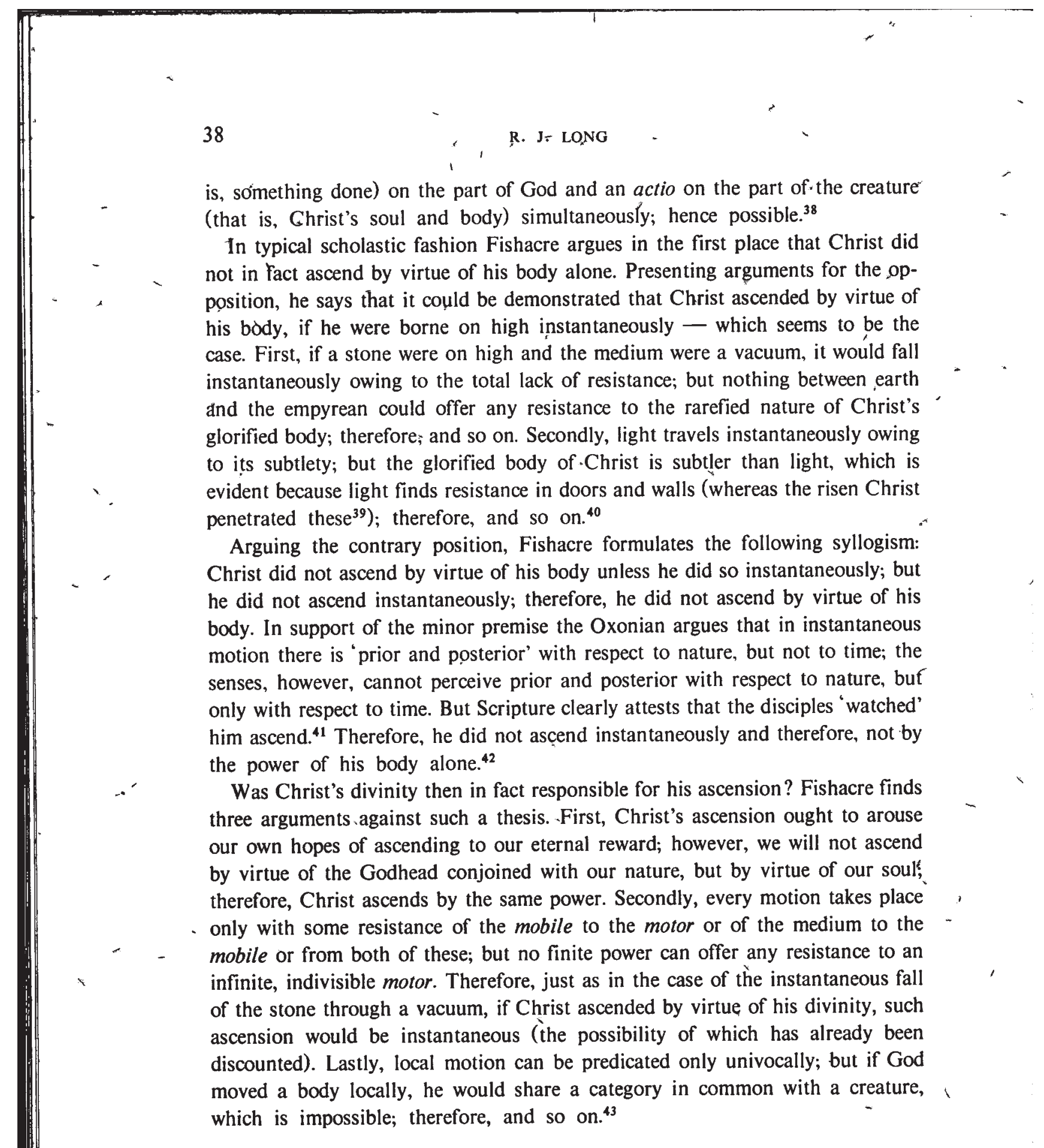

38 p. 52.

39 See Jn 20:19.

40 pp. 52-53.

41 'Cumque intuerentur in caelum euntem illum ...' (Ac 1:10).

42 p. 53.

43 ibid. 
To the second and third objections Fishacre has a response. The need of resistance for motion to take place obtains only for natural motion, not voluntary motion (which would be the case with a divinely caused ascension). Univocal predication, moreover, is avoided by once again positing the distinction between, actus (predicated of God) and actio (predicated of the creature); only the latter is - an accident, the former being identical with God's very being. ${ }^{44}$

- Fishacre thus seems most inclined to the third option, namely, Christ's ascending by virtue of his soul. Motion, he asserts, is either natural, voluntary or forced; but voluntary procession is solely from the soul. Since the Ascension, however, was gradual (again the authority is the text from Acts ${ }^{45}$ ), it evidently took place by virtue of the soul. ${ }^{46}$

Opposing arguments are presented as follows: gradual motion requires resistance; must we suppose, therefore, that Christ increased the density of air, 'fire, and heaven itself (as he once did that of the sea ${ }^{47}$ ) so that he could ascend gradually? Such does , not seem to be necessary, replies Fishacre, since no resistance (in howsoever solid a body) can be found to the glorified body. ${ }^{48}$

Tentatively (and characteristically) Fishacre offers his conclusion that Christ's gradual ascension took place either by virtue of the soul alone or by virtue of the composite of soul and body, such that the soul or the divinity would have retarded the instantaneousness (subitatio) with respect to the body. ${ }^{49}$

In the final analysis, however, the matter exceeds the capacities of human knowledge, as the Lombard says in his gloss on the Psalm text 'Et ascendit super cherubim'. ${ }^{50}$ In fact, according to Peter L'ombard's gloss on another Psalm, it would seem that it was by virtue of Christ's divinity that he ascended. Neither can Fishacre find anything conclusive to say about the gradual nature of the Ascension. ${ }^{51}$

Finally, posing a new question, the Dominican asks in what direction Christ ascended. Scripture seems to offer contrary views, that is, toward the east and toward the west. After considering several alternate views offered by the Lombard, Fishacre concludes the quaestio by suggesting a literal interpretation based on one of the suppositions of contemporary geography: namely, that Jerusalem (the site of the Ascension) occupies the midpoint between east and west in the belt or climate of the earth which we inhabit. When the sun makes its daily cir-

44 p. 54.

45 Ac $1: 10$.

46 p. 54.

47 See Mt 14:25: Mk 6:48: and Jn 6:19.

48 p. 54.

49 ibid.

50 Ps 17:11.

51 p. 54 . 


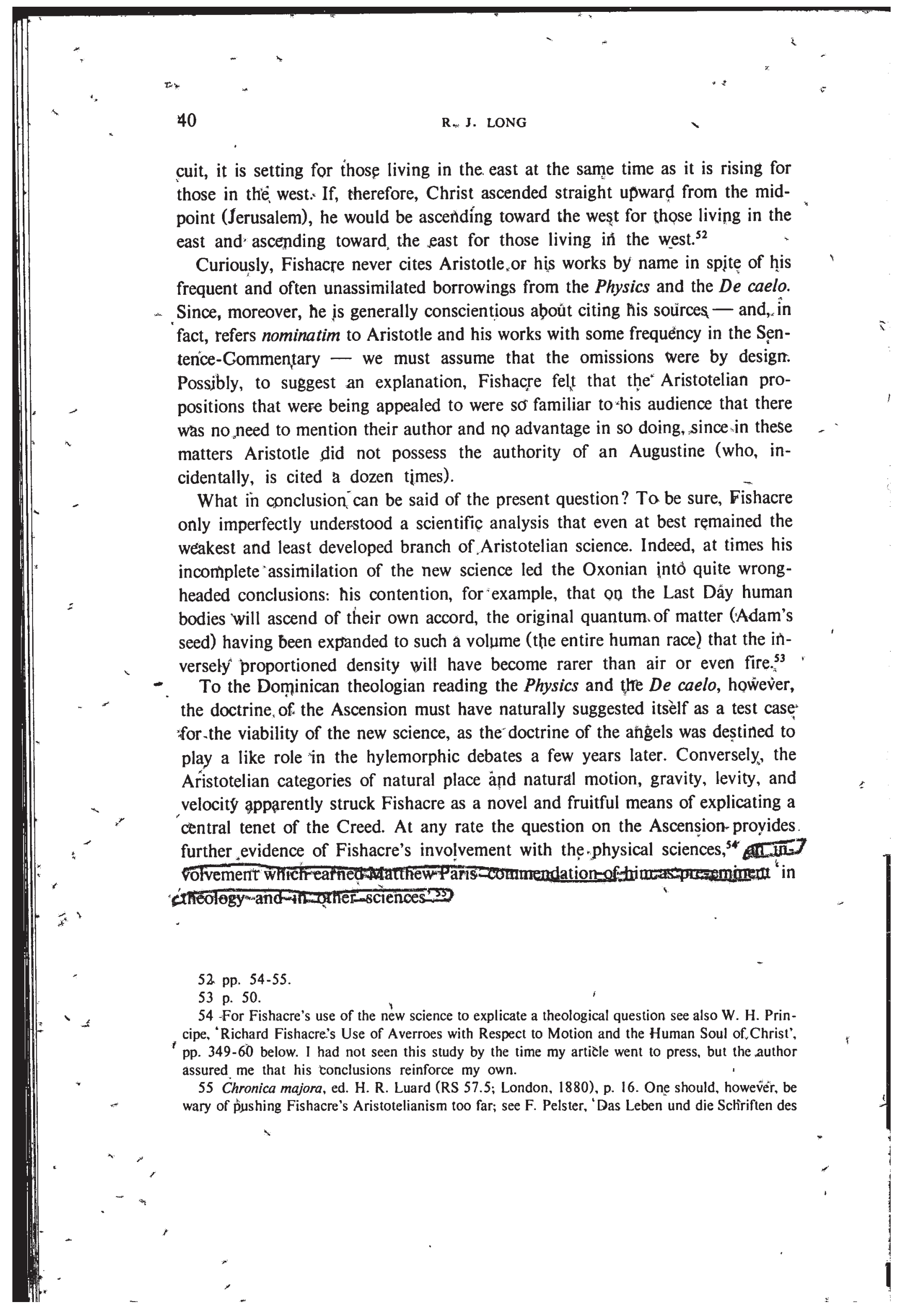


"That Fishlhacre answeréd the problems posed."by Aristotle by appealing to ${ }^{\text {" }} \mathrm{St}$. Augustine, moreover, is not in the least surprising. His vision was still "informed by traditional Christian. Platonism. and in that tradition.Augustine remained the authority par excellênce. Fishacre, to borrow his own imagery, was willing to eñtertain a dalljance with the handmaiden, science, but was Joath to tarry in ber chambers. The queen was waiting, and it was by her that Fishacre desired to bear fruit.

\section{w. The Manuscript and Edition}

Only one copy of Fishacre's quaestio on the Ascension is extant: Vatican MS. Ottỏb. lat. 294 , fols. $294 \mathrm{vb}-296 \mathrm{rb} .{ }^{56}$ The same codex also contains a copy of Fishacre's Commentarium in libros Sententiarum (fols. 1r-286v), ending with book 4, distinction 8, and also an untitled and anonymous work containing ad-

1 'notationes on Augustine's De haeresibus (fols. $287 \mathrm{r}-294 \mathrm{v}$ ). The lattér is probably also from the pen of Fishacre.'

The manuscript is of English origin, in a small hand and more than usually abbreviated. It has page, column, and line numberings in fives - the latter a peculiarity of a mid-thirteenth-century Oxford scriptorium which serves to iden-* tify the earliest Fishacre manuscripts. ${ }^{57}$ Judging from its script, its line numberings, and especially its affinity with Paris, Bibliothèque ,Nationale MS. lat. 16389, thought to be copied during Fishacre's lifetime, ${ }^{58}$ I would date the manuscript to the third quarter of the thirteenth century. ${ }^{59}$

Oxforder Dominikanạerslehrers Richard Fishacre (d. 1248)', Zeitschrift für katholische Theologie 54 (1930) 538. In discussing Fishacre's philosophical position Gilson remarks: '... the queștion arises whether Aristotle himself would have been able to understand the meaning of his main positions' (History of Christian Philosophy in the Middle Ages [New York, 1955], p. 354),

56 The verso side of fol. 296 is free of text, suggesting that the question is complete. The manuscript is described in Inventarium codicum MSS latinorum Bibliothecae Ottobonianae 1.294; F.' Ehrle, 'L'agostinismo e l'aristotelismo nella scolastica del secolo XIII', Xenia Thomistica 3 (1925) 553; Pelster, ibid., 526-27; and Long. 'Science of Theology', 77. It was first identified by A. Landgraf in Das Wesen der lässlichen Sünde in der Scholastik bis Thomas von Aquin (Bamberg; 1923), p. 105.

57 This unusual device is shared by five manuscripts containing Fishacre's SentenceCommentary. See Pelster, ibid., 522.

58 This Sorbonne, manuscript, which ends with dist. 3 of book 2, contains the following petition, on fol. 9av: 'Rogo te, lector, quisque es, ut roges Deum pro fratre Richardo de'Fixacre, qui hoc opus" edidit, ut eum Dominus nunc et semper in anima custodiat et in corpore vires prebeat, ut residuum operis ad finem prospere perducat. Amen.' The writer of these lines apparently believed Fishacre to be still alive; hence we may affix a pre-1248 date to the codex. See Long, 'Science of Theology', 77.

59 Ehrle without further explanation places the manuscript in the fourteenth century ('L'agostinismo', 553). 
Since the manuscript is unique, I decided to preserve as faithfully as possible the orthography of the scribe, including the inconsistencies (e.g. ignis and. ingnis). Whenever the spelling was so unusual or strange in appearance as possibly to engender confusion, I noted the more usual spelling in the apparatus (e.g. opagum for opacum). It will be noted that tia/ tio becomes cia/ cio following $i$ or a liquid (e.g. resistencia). The punctuation and capitalization are mine.

- I have emended with reluctance, and then only when I felt it necessary in order to preserve the sense. Obvious omissions and dittographies I have corrected in the text without further explanation by the use of pointed and square brackets, as follows:

$<>$ signifies letters or words to be added;

[ ] signifies letters or words to be omitted.

I wish to acknowledge my gratitude to the Fulbright Commission for enabling me personally to study the manuscript at the Vatican Library and to Fairfield University for a grant covering the preparation of the article. 


\section{RICHARD FISHACRE, $<$ DE ASCENSIONE CHRISTI $>$}

6. (f. 294vb) Quesitum fuit de ascensione: qua uirtute Christus ascendit? Et primo utrum uirtute solius deitatis potuit ascendere. Et patet quod sic. Si enim illa manus Dei, scilicèt Filius Dei, tribus digitis appendit mo[bi]lem terre (Is $40^{\mathrm{a}}$ ), quanto magis corpusculum assumptum? Num 11: Numquid manus Domini inualida est? ${ }^{\text {b }}$ Luc: Non ${ }^{1}$ erit inpossibile apud Deum omne uerbum. ${ }^{\mathrm{c}}$

2. Quod autem uirtute anime, probatio. Nobiliori creature debetur locus superior. Ergo omni anime rationali debetur națuraliter locus suppremus. ${ }^{d}$ Sed fertur unumquodque ad locum suum non prohibitum. ${ }^{e}$ Ergo et cetera.

3 .Item angelus ${ }^{2}$ et anima natura sunt pares. ${ }^{f}$ Ergo et locus naturalis eis par aut idem. Sed angelorumm locus est celum. Ergo et animarum.g

4. Item quod omnibus inest, naturale est, ut dicit Augustinus. ${ }^{\text {h }}$ Sed appetitus illius (f. 295ra) bone ${ }^{3}$ habitationis omnibus inest. Ergo est naturalis. Ergo secundum

Is $40: 12$.

b Num $11: 23$.

c Lc 1:37.

d. Cf. Fishacre: "Item materia et sua per se forma proporcionantur ita ut nobilioris materie sit nobilior forma et e converso. Sed forma corporis humani est nobilissima, scilicet anima rationalis. Ergo ipsum est nobilissimum. Ergo naturaliter ei debetur locus suppremus' (2 Sent. 14; Cambridge. Gonville and Caius Coll. MS. 329/410 ( = C), fol. 188rb and Oxford, Balliol Coll. MS. 57 (= B), fol. $109 \mathrm{ra}$ ).

- Cf. e.g. Aristotle, De caelo 1.8 (276a23-28).

\& Cf. Augustine, De libero arbitrio $3.11^{\circ}$ (CCL 29.294): "Animae sunt enim rationales, et illis superioribus officio quidem impares sed natura pares'.

- Cf. Fishacre: "Quorum est eadem natura, idem est locus naturalis. Sed anime rationalis et - angeli est eadem natura, quia, ut dicit Augustinus, sunt natura pares et officio dispares. Ergo eorum est idem locus naturalis. Sed locus omnis compositi naturalis est locus naturalis predominantis in ipso. Ergo cum homo compositus sit, et in eo pars predominans sit anima, locus totius hominis naturalis est locus anime: sed locus anime. ut ostensum est. celum est. Igitur et locus totius hominis naturalis celum est' (2 Sent. 14: C, fol. 188 ra and B, fol. 109 ra).

h In his Sentence-Commentary (see i below) Fishacre gives as his source the Unde malum, the title under which the first book of the De libero arbitrio was known-in the Middle Ages; I was unable, however, to locate the source of this quotation.

1 bene MS.

2 augustinus MS.

3 bene MS. 


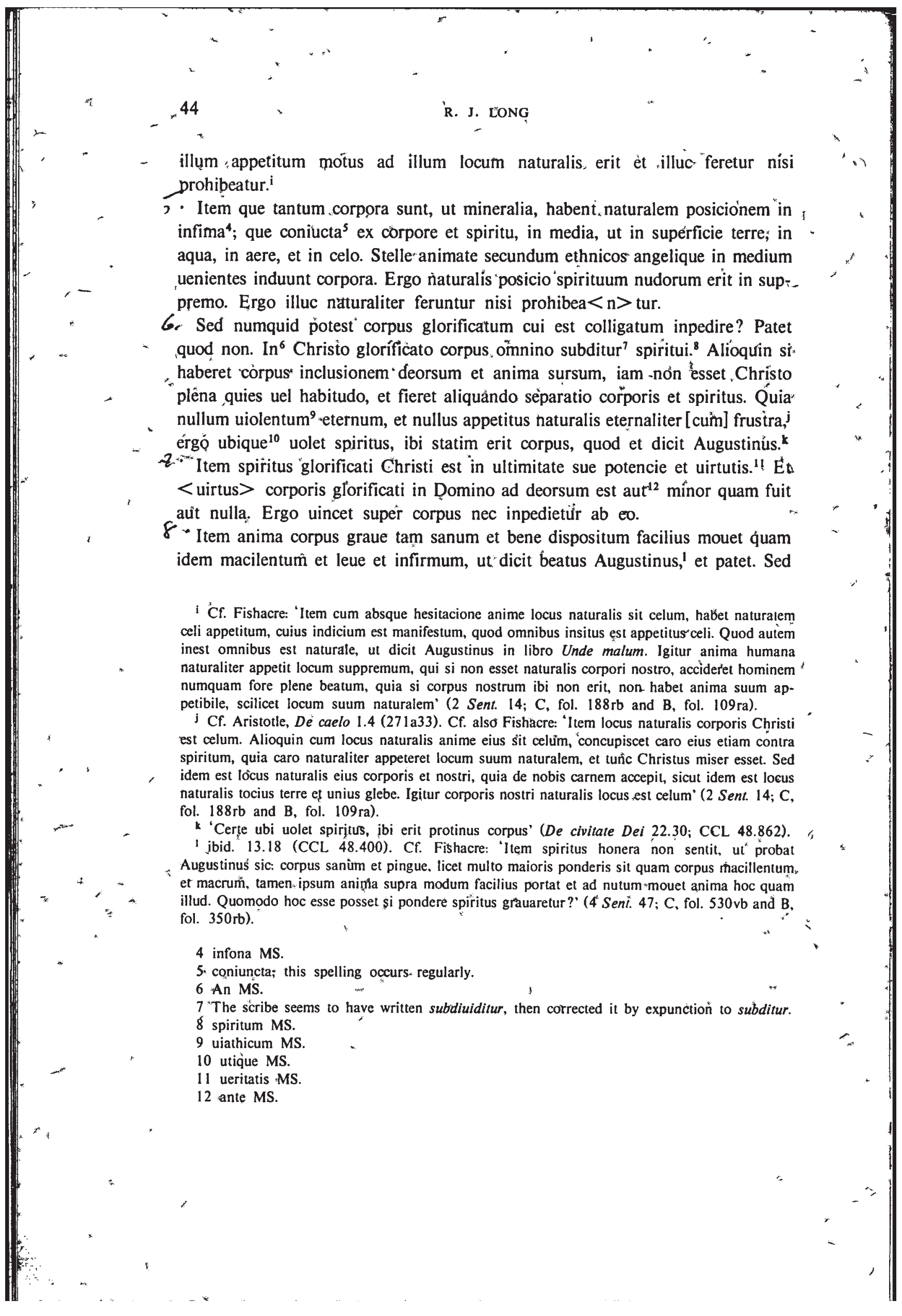




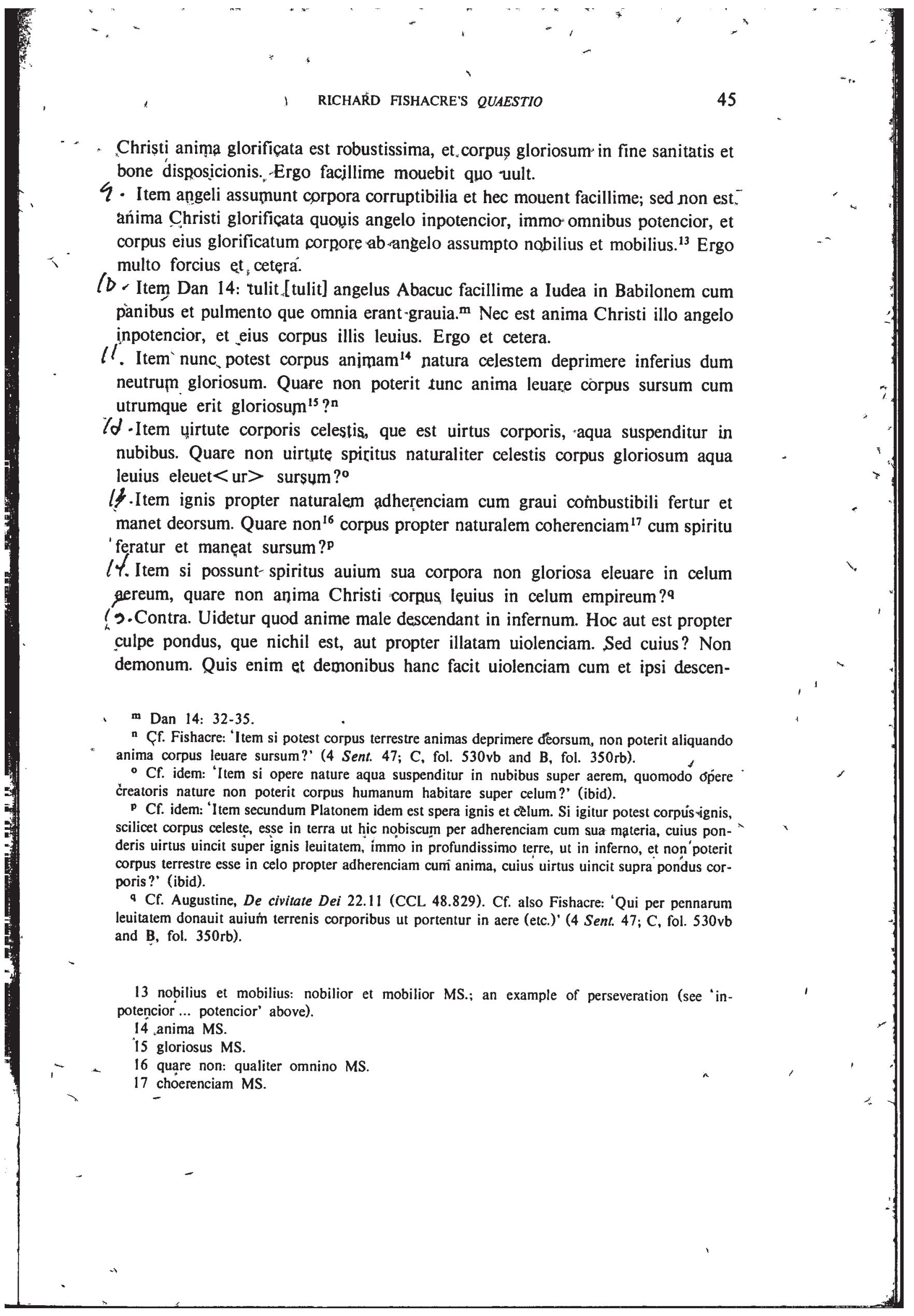




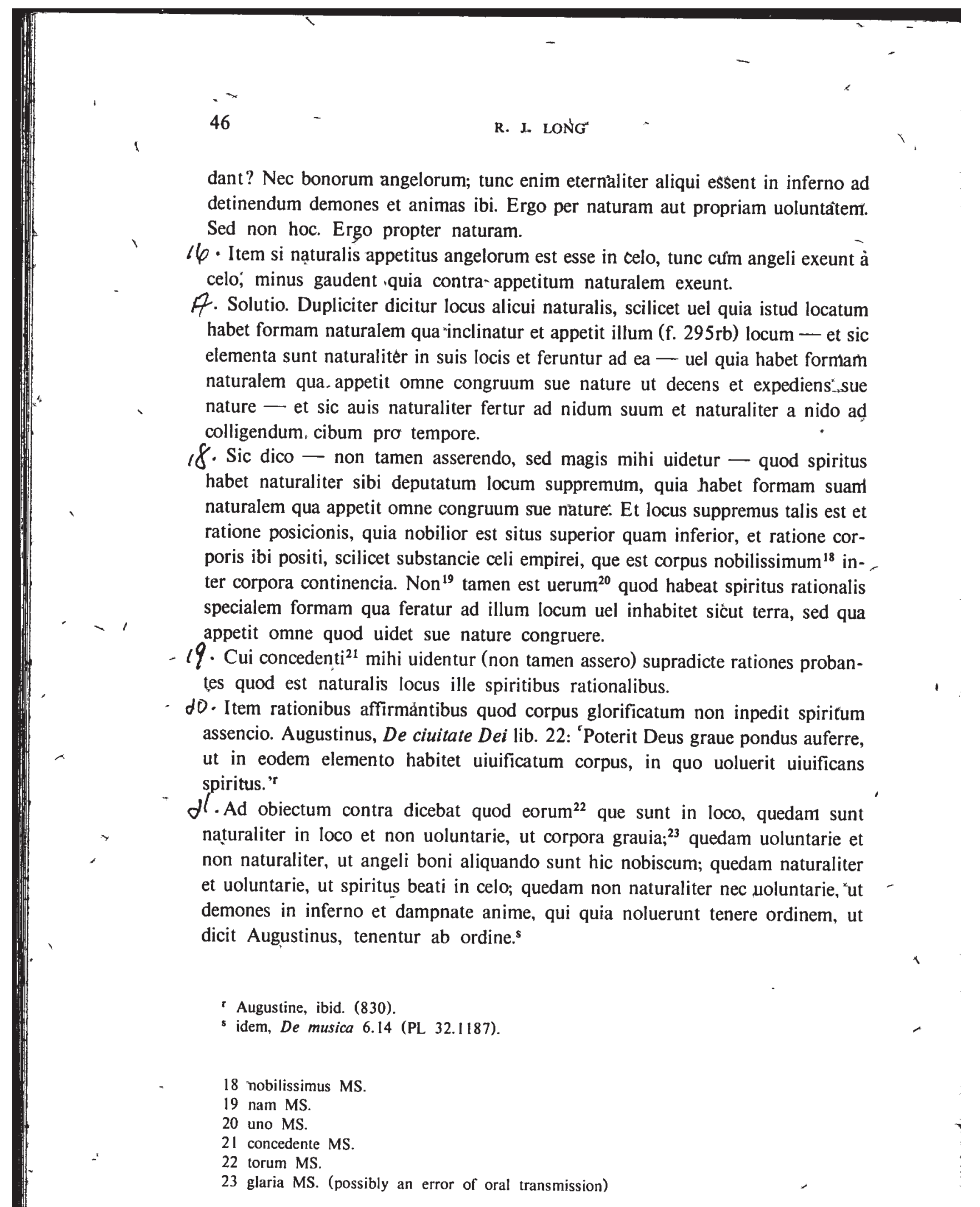


$2 \alpha$. Sed qua ui teneantur dampnati ${ }^{24}$ spiritus in inferno," nescio. Dici tamen posset, nisi aliquid melius uideatur, quod illa uirtus detinet uiolenter illos spiritus naturaliter celestes que detinet aquas uiolenter superius - dico aquas que super celos sunt. Sed aquas detinet sursum quia forte expedit et spiritus tales deorsum quia decet et congruit. Licet enim deformes sint, tamen ornare possunt - illam uilem habitationem et penalem, sicut latro ornat carc $<\mathrm{er}>\mathrm{em}$, ut dicit Augustinus, De libero arbitrio, ${ }^{t}$ et eadem ui possunt detinêri in illis ingnibus ${ }^{25}$ qua ille ingnis in loco infimo. ${ }^{26}$ Uel aliter (quod nec assero) dicit Augustinus;,$D e$ ciuitaté Dei lib. 21: 'Adherebunt spiritus incorporei corporeis ingnibus cruciandi meris et ineffabilibus modis, accipientes ex ingnibus penam, non dantes ingnibus uitam.' 'Sic ergo uidetur quod aliqua sit colligatio spiritus dampnati cum illis ingnibus, licet non talis omnino qửalis est anime cum corpore. Et tunc, ut uidetur, posset diči quod ministerio demonum illuc ueniunt et ibi uirtus diuina colligationem hanc facit cum illis ingnibus et ita uiolenter ibi per similem colligationem detinêntur.

12. Ad hoc quod dicis quod naturaliter sunt angeli in celo, uiolencia fit eis et minuitur eorum ${ }^{f}$ gaudium cum huc ueniunt, respondeo: Duo sunt: gratia uel uirtus, et natura. Et opus gratie uel uirtutis 'non est uiolentum nec nature, sed secundum naturam et supra naturam ${ }^{27}$ ad eius melior $<$ itat $>\mathrm{em}$. Dici ergo potest quod in angelis est natura et gratia, et natura illa tota quasi absorta ${ }^{28}$ a gratia est. Et ideo potest gratia super naturam, et ideo plus deletantur ${ }^{29}$ in operibus gratie ut atemperando diuine uoluntati huc ueniendo quam prout congruit sue nature ( $f$.' $295 \mathrm{va}$ ) illic manendo. Et ita huc uenire et non est contra naturam sed potius secundum naturam sicut opus uirtutis. Qui ${ }^{30}$ appetit illic manere quia congruit sue nature, appetit pro tempore huc uenire quia uidet Deum hoc uelle, et quia plus pótest in eis amor Dei quam sui, mauult huc uenire cum uidet Deum hoc uelle quam illic manere. Et sicut non est ui $<0>$ lencia nec contra naturam quod amat Deum plus quam se, sic nec opus ab amore egrediens et per hoc essent in angelis huc uenientibus appetitus non contrarii sed duorum incompossibilium, ${ }^{31}$ scilicet

' idem, De libero arbitrio 3.9 (CCL 29.292).

u -idem, De civitate Dei 21.10 (CCL 48.776).

24 dampnari MS.

25 ignibus; this spelling is by far the more common.

26 infinco MS.

27 secundum materiam et supra materiam MS.

28 absorpta

29 delectantur

30 cui MS. (an error of oral transmission)

31 inçompossibilem MS. 
esse ibi $<$ et esse hic $>$. Sed unus est nature et alter est uoluntatis informate. ${ }^{32}$

* Nec sunt hec diuisa contra se propter hoc quia uoluntas informata uult quod natura hoc uelit quod uult, sicut caro Christi, que noluit ${ }^{\hat{3}}$ mori, non tủnc cupiscit $^{34}$ aduersus spiritum ${ }^{\mathrm{v}}$ qui uoluit carnem mori, quia spiritus uoluit carnem sic uelle.

J4. Uel posset dici, sicut uidetur dicere Damascenus ${ }^{\mathbf{w}}$ et Crisostomus ${ }^{\mathrm{x}}$ de Christo, quod deitas que potuit super Christi humanitatem nunc permitebat eam somni $<a>$ re et pati, et. agere humana, nunc autem non. Sic uoluntas informata si potest super naturam sibi iunctam intantum ut actum sumum ad tempus non sinat agere, scilicet appetere illud lignum ${ }^{35}$ tunc esse, hoc non est contra naturam sed supra naturam.

do 'Quod autem uirtute corporis solius glorificati potuit ascendere uidetur, quia nobilior $<i>$ corpori debetur locus superior. ${ }^{y}$ Sed corpus Christi nobilissimùm. Ergo ei debetur locus suppremus.

26. Contra. Secundum hanc rationem esset sol superior omnibus stellis. Item cum locus suppremus [sic], scilicet celum empireum, sic plenus corpore esset, sịc corpus Christi et extra empireum.

27. Sed respondeo: prima est uera in corporibus ornantibus ${ }^{36}$ ad inuicem, ut in speris, [et in corporibus ornantibus ad inuicem] nisi utilitas contrarietur uniuersi. 'Forte enim soli est inditus ${ }^{37}$ naturaliter maior appetitus loci medii propter utilitatem u̧niuersi quam locị suppremi ${ }^{38}$ propter suam nobilitatem - quorum nullum inpedit rationem de corpore Christi.

18 Item nobilius non fit propter innobilius. Sed celum et stelle sunt propter hominem, etiam propter corpus. Deu 4: Ne forte uideas solem et lunam et uniuer-

* sas stellas quas creauit Deus in ministerium cunctis gentibus. ${ }^{2}$ Igitur non seruien- $^{-}$ dum sideribus sed ipsa potius ${ }^{39}$ seruiunt nobis. Ergo cum ministrorum sit ${ }^{40}$ etiam -

vf. Gal 5: 17.

w John Damascene, De fide orthodoxa 58.5, trans. Burgundio of Pisa, ed. E. M. Buytaert (St. Bonaventure, N.Y., 1955), p.' 217.

$\times$ I was unable to find this reference in any of Chrysostom's authentic works; Fishacre is here most likely paraphrasing from a secondary source.

y Cf. Aristotle, De caelo 2.13 (293a30-32).

2 Deut 4: 19.

32 informare MS.

33 uoluit MS.

34 cupit ac MS.

35 illud lignum: illum linum MS.

36 ornans MS.

37 indicas MS.

38 suppremum MS.

39 post MS.

40 sic MS. 
localiter subesse, Dominus: Nisi sicut paruuli, ${ }^{2}$ secundum illud Gal 4: Quanto tempore heres paruulus est, non differt a seruo, cum sit dominus omnium; sed sub 'tutoribus'1 et a[u]ctoribus est usque ad prefinitum tempus a patre. ${ }^{\text {b }}$ Sed si nobilius, naturaliter superius.

$\alpha$ G. Item anima, cum sit quiddam celeste, detinetur naturaliter in celesti habitatione, noń uiolenter. Quidam hanc ei infert uiolenciam, cum possit homo se ipsum-occidere. Quare erg̉o non potest terrenum naturaliter habitare in celo, et sic mouere potest illud ${ }^{42}$ naturaliter?

30 Et maior est differencia corporis ad spiritum quam corporis ad quodcumque, .$^{-}$corpus, et habitat spiritus in cörpore naturaliter. Quare non potest naturaliter $<$ habitare $>$ corpus quodcumque in quociumque?c

- $3 /$. Contra hec: "Idem est locus naturalis tócius terre et unius glebe. ${ }^{\text {dd }}$ Ergo si gle(f. $295 \mathrm{vb}$ )ba corporis Christi naturaliter sursum est, et tota terra - saltem cum erit glorificata.

अ. Respondeo. Prima "uera ${ }^{43}$ est de gleba úel athomo ${ }^{44}$ terre "non" unita alteri et" nobiliori maxime qualis est terra in corpore Christi, et si non esset maior glorificatio terre in corpore Christi quam tocius terre erit, tưnc idëm esset eorum locus. Item idem tocius et partis [idem] est locus, quia in utroque eadem est inclinatio. ${ }^{.}$Sed ut ùidetur sentire Augustinus in fine precedentis pagine in auc-

- toritate premissa uel ultima[m], auferetur terre in corpore glorificato humano pondus et forte non auferetur hoc toti terre glorificate. ${ }^{f}$ Et ita non idem locus̀.

3f -Item uniuersaliter coniucta sunt grauitas et grossicies uel densitas, ut patet in -elementis._. Et quod est grossissimum uel densissimum est grauissimum. Ergo

Mt 18: 3 .

b Gal 4: 1-2.

c Cf. Fishacre: 'Sed contra eos arguitur multipliciter ibidem ab Augustino (cf. De civitate Dei 22. 4 [CCL 48.809-10]): Si potuit Deo agente spiritus, qui est tamen cêlo nobilior, habitare in terra ut in terrestri corpore, quare non potuit eodem agente non uiofenter cogente corpus terrestre habitare supra celos? Maior enim supra modum est differentia spiritus ad corpus̊ quam unius cór-* poris ad quodcumque aliud. Mirabilius est igitur spî́ritum habitare in corpore ferreno quam corpus terrenum in corpore celesti' (4 Sent. 47; C, fỏl. 530va-b and B, fol. 350ra-b).

d Aristotle, Physics 3.5 (205al0-11).

e Cf. idem, De caelo 1.3 (270a3-5).

See $n$. $r$ above. In fact, this passage is cited on the preceding page of the manuscript (fol. $295 \mathrm{r}$ ), approximately a third of the way down in the second column. While not precisely "at the end of the preceding page', this method of cross-referencing suggests a unique copy.

8 Cf. Aristotle, De caelo 1.6 (273b3-5).

41 autoribus MS.

42 fort. illuc legendum est.

43 natura MS.

44 achomo MS.

$-$

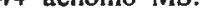


subtillissimum corpus, scilicet glopiosum, cuius des subtilitatęm, ${ }^{45}$ erit deuisšimum.

345 Item quanto ex minori fit magus, ${ }^{46}$ tanto factum est subtilius: ${ }^{\text {h }}$ ut si ex pugillo terre fiant centum, factum erit subtilius quam si ex ea tantum $\mathrm{X}$ fierent. Igitur cum uera humana caro non fit nisi dé semine Adam, illud modicum factum est uehementer magnum. Et erit in die iudicii, cum erunt corpora tot humana completar, nullo addito, illi materie seminis Ade, et subtiliora, si computes, quam siessent omnino ingnis uel celum. Ergo cum subtilius sit naturaliter superius, erunt corpora superius et supra celum stẹllatum. Et sic corpus Christi.

35. Item quanto leuius tanto mobilius, et quainto ponderos $<i>$ us tanto immobilius, ut patet in elementis. Et ideo spera terre omnino inmobilis, spere elementorum moueantur. Sed corpus Christi est summe agile propter dotem agilitatis. Ergo summe leue:

36 Item opagum ${ }^{47}$ infimum, diafonum medium, et luminosa, ut ignis et stelle, ${ }^{48-}$ sursum sunt; naturaliter ergo et corpus gloriosum ratione dotis ${ }^{49}$ que est claritas. Unde conparat Appostolus $\mathrm{ea}^{50}$ stellis dicens Cor 15: Alia claritas solis, alia lune, alia stellärum; stella $[\mathrm{m}]$ enim a stella $<$ differt $>$ in claritate. Sic et resurrectio 、" mortuorum. ${ }^{\mathrm{i}}$

3. Item ut ponit Plato et Basilius, ', 'facit Deus', id est aufert ingni urendi qualitatem manęnte qualitate Jucendi, quia lux ingnis emicat per oculos. Sed quare non similiter in elementis potest separare grauitatem aliis qualitatibus manentibus?" Augustinus, epistola 73: 'Ualet diuina potencia de ista uisibili atque tractabili materia corporum, quibuslibet manentibus, auferre quas uoluerit qualitates.'

h Cf. ibid. 3.7 (305b13-16).

i 1 Cor 15: 41-42.

j Timaeus 45B; probably quoted from Augustine, De civitate Dei 13.18 (CCL 48:401).

k Homilia in Hexaemeron 6.3 (PG 29.122).

1 Possibly a reference to Gen i: 16 , ('Fecitque Deus duo magna luminaria'), the text upon which Basil is here commenting.

m Cf. Fishacre: 'Item si, ut dicit Basilius, Verbo Dei separabitur in igne lux ab ustione et, ut dicit Plato, dii qui hominem fecerunt secundum eum potuerunt separare ab igne urendi qualitatem et lucem relinquere que per oculos emicaret, quare non poterit a resurgentium corporum terra auferre ponderositatem, natura terre remanente?' ( 4 Sent 47 ; C, fols. $530 \mathrm{vb}-531 \mathrm{ra}$ and B, fol. $350 \mathrm{rb})$.

"Epist. 205.1 (CSEL 57.326-27).

45 subtilitas MS. (possibly an error of perseveration)

46 maius

47 opacum

48 stellas MS

49 docis MS.

$50 \mathrm{ca}$ MS. 
Itęm uniuersaliter in sacramento altariş est accidens sine omni subiecto. Quare non potest fieri ut subiectum sit saltem sine aliquo accidente, scilicet grauitate? 37. Item non plus ponderat hostia consecrata quam prius cum fuit non consecrata et constat <quod> pondus in consecrata est non corporis Christi secundum $<$ modum $>$ accidencium; nec est in corpore Christi illud pondus magis quam illa albedo. Ergo cum pondus primum remaneat nec modicum additur ponderi post cońseçrationem, corpus Christi nullius ponderis est uel potest esse aliquando sine pondere. Quare non ergo in ascensione?

40. Contra. Eadem ratione uidetur quod non sit "leue quia non est ạucta leuitas post consecrationem.

Item nullum uiolentum eternum, ${ }^{\circ}$ quia si sol eternaliter esset sursum uiolenter, motus contrarius esset ei possibilis et potencia respectu talis motus frustra. Igitur cum corpus Christi sit in celo - et hoc eternaliter - non erit uiolenter. (f. 296ra)

12 Item omnes spere integre sunt 4 , scilicet terre, aeris, celi siderei, empirei. Hinc frequenter dicitur coniucti $<\mathrm{m}>$ 'celum et terra'p ut comprehendat $<$ ur $>$ 'omnis creatura'. Solum ${ }^{51}$ enim triplex est: aereum, sidereum, empireum. Aqua non habet speram, quia non undique tegit terram. ${ }^{9}$ Unde apud phisicos una ${ }^{52}$ spera reputatur. ${ }^{r}$ Angelis spera seçundum sanctos non est nisi celum. Sunt autem inter ornancia corpora innobiliora ${ }^{53}$ opaga et nobiliora lüminosa; et opacorum inanimata innobiliora quam animata. Prima sunt ornatus terre. Secunda sunt naturalis ornatus aeris. Tercia, scilicet luminosa inanimata, sunt ornatus celi siderei. Ergo luminosa animata sunt ornatus celi empirei. Et sicut stệlla* sursum feretur naturaliter, sic corpus gloriosum, quod, ut dicit Augustinus, auferet[ủr] Deus grauitatem elementis componentibus corpus glórificatum.s ${ }^{s}$ Sed utrum leuitatem ingni in eodem corpore non dicit. Si ergo manet in eis leuitas naturalis et nulla grauitas, ascendit sursum naturaliter saltem usque ad locum suppremum spere ignis, et si non est alia spera ignis nisi celum sidereum, usque ad celi siderei suppremum. Et quia ingnis in illo corpore est nobilitatus supra ${ }^{54}$ naturam celi siderei, adhuc ascendet hinc, ${ }^{55}$ sicut si faceret Deus celum nobilius super hoc

- Cf. Aristotle. De caelo 2.14 (296a33-34).

p See n. 34 (p. 36 above).

q Cf. Aristotle, De caelo 2.4 (287bl-14).

'Cf. ibid. (287bi15).

s De civitate Dei 13.18, 22.11 (CCL 48.401, 829-31). •

51 i.e. 'the vault' (of the heavens); fort. celum legendum est.

52 fort. uniuersum legendum est.

53 in hora MS.

54 sic MS.

55 huic MS. 
celum sidereum et esset utrum< $<$ que $>$ leue quia ingnis, pars celi nobilioris, si $*$ esset inferius, ascenderèt ${ }^{56}$ superius naturaliter.

45. Si autem aufert Deus, leuitatem sicut et grauitatem, ut nec sit graue nec leue corpus glorificatum, tamen licet.non hąberet formam qua mouerẽtur sursum sicut nec qua deorsum, habet tamen naturaliter inditum sibi appetitum eorum que congruunt sue nobilitati, scilicet situm ${ }^{57}$ suppremum et continens nobilissimum, et isto appetitu naturali, ex quo nullum inpedimentum, feretur sursum; ut mihi uidetur - non assero tamen. Et si stella non est grauis uel leuis, si esset extra. suum locum, consimili appetitu ferretur ad suum locum.

4f. Exemplum est ignis: non habet figuram naturalem ${ }^{\mathrm{t}}$, maxime ${ }^{58}$ figuram pinealem. ${ }^{59}$ Unde in sua spera non habet figuram sed uel a celo continente[ $[\mathrm{m}]$ rotundam uel, si est celum, naturaliter habet figuram speralem; nunc tamen hic - figurat se figura pineali, quia non habet formam naturalem qua sic. figuretur ( $t u<n>c$ enim sic figuraret ubique). Sed quia formam habet naturalem qua ap-. petit cóngruencia sue nature, et ideo colligit se in figuram penetratiuam, qua penetret ad locum superiorem.

46. Sic ergo patet quod uirtute et deitatis per se et anime per se et corporis per se potuit ascendere.

4. Sed cum uirtute singulorum potuit ascendere ille, queritur qua uirtute äscendit. Non uirtute omnium simul, quia nulla actio Deo et creature communis est. Augustinus, epistola 125: 'Nichil omnino ${ }^{60}$ a duobus idem fieri ${ }^{61}$ potest.'u Solutio. Illa actio posset esse actio creature et actum Dei. Sermo autem Augustini intelligitur in coequeuis agentibus ex quibus non fiat unum.

48. Sed probatio quod uirtute corporis, $\mathrm{si}^{62}$ ipsưm fer $\langle\mathrm{r}>$ etur sursum subito, demonstraretur - quod sic uidetur. Lapis si esset sursum et medium uacuum, fieret lapis deorsum subito propter nullam medii resistenciam." Sed nichil inter

t Ef. Aristotle, De caelo 3.8 (306b30-307b26).

i I was unable to find the source of this quotation. Cf. Fishacre: 'Item, ubi est diuersitas agentium, nisi ex eis fiat unus agens, et diuersitas actorum' (4 Sent. 44; C, fol. 515ra and B, fol. $338 \mathrm{vb})$.

$\checkmark$ Cf. Aristotle, Physics 4.8 (215bl-6) and De caelo 4.4 (313bl7-22). Cf. also Fishacre: 'Item ad hoc quod sit motus exigitur necessario aliqua resistencia in moto respectu motoris' (4 Sent. 44; C, fol. $518 \mathrm{rb}$ and $\mathrm{B}$, fol. $34 \mathrm{lra}$ ).

56 ascendit MS.

57 sicum MS.

58 fort. magis legendum est.

59 literally 'pineal' or 'shaped like a pine cone'.

- 60 oratio MS

$61 \mathrm{fm}$ (?) MS

62 quia MS. 


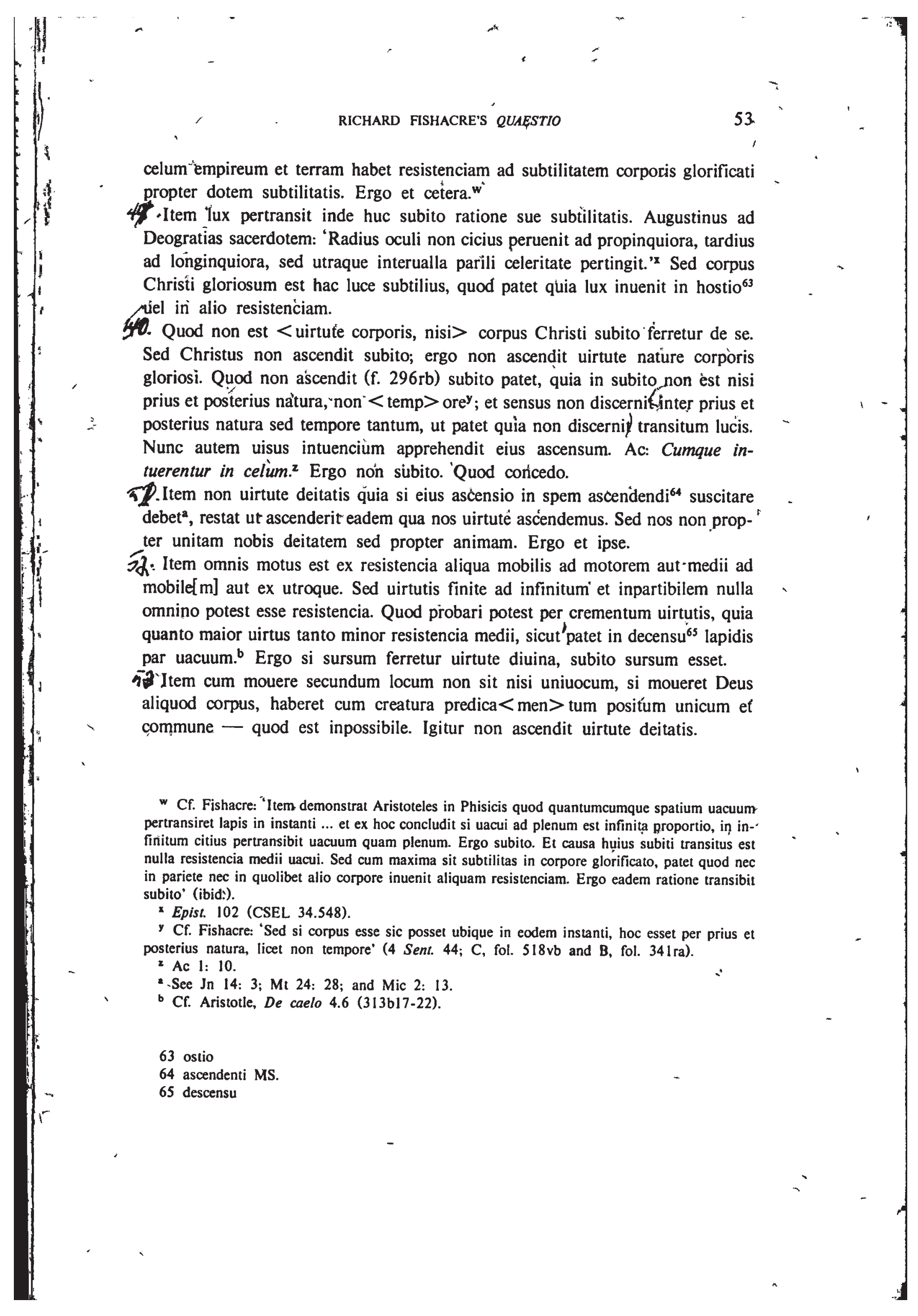


64. Responde: quod dicitur 'non est motus úbi non est resistencia' medii ad potorem'c, uerum tantum ${ }^{66}$ in motu naturali, non uoluntario.

36. Ad aliud 'mouere secundum locum': de Deo dictum est motum esse actum Dei. De creatura uero dictum est esse actionem creature,. et ita non uniuoce.

56. Cui ${ }^{67}$ 'ascendit uirtute anime', que habet uirtutem particularem, quod etiam uidetur. Cum enim sit motus naturalis, uoluntarius et uiolentus. Sed processús uoluntarius est solum ab anima. Cum ergo Christi ascensus fuerit processiuus, patet quod fuit ab anima. Ac 1: Cumque[que] intuerentur in celum euntem illum. 5ed contra. Motus processiuus est super uiam habentem aliquam resistenciam. Numquid ergo sicut mare solidauit ${ }^{\mathrm{e}}$, sic nunc aerem, ignem, et celum? Sed non uidetur quia nulla ad corpus gloriosum in aliquo corpore resistencia.-

58. Solutio. Non assero, sed mihi uidetur quod potuit sic successiue à$c e<n>$ disse uirtute anime solius uel coniucti ex corpore et anima, scilicet ut anima subitationem illi corpori retardaret uel deitas. Sed cuius uirtute factum sit, nescio, quia ascendit super cherubin ${ }^{\mathrm{f}}$, id est, ascensio eius 'omnem modum sciencie excedit', ut dicit ibi Glossa." Uidetur tamen quod uirtute 'deitatis; sic'qui" ascendit super celum celi ad orientem ${ }^{\mathrm{h}}$, Glossa: 'Oriens intelligitur Uerbum a Patre genitum, cuius uirtute ascendit. ${ }^{i}$ Sed an uirtute anime et grauis interdum est, nec certum inuenio et ideo non dico.

ร7. Utrum etiam ascendit motu processiue, nesçio nec de hoc aliquid fixum inuenio. Nec necesse/fuit solidari aerem, cum Christi corpus non habeat grauitatem.

60 3 ${ }^{\prime} \cdot$ Sed qua ascendit? Uidetur quod per occidentem; 'Ps: Quị super occasum.j" 61 Item uidetur quod per orientem; Ps: Qui ascendit super celum celi ad orientem. ${ }^{\mathbf{k}}$

61.Solutio. Ascendit super occasum', id est, 'mortem corporis quam -resurgendo uicit. 'm' Et ita fit hic mencio de resurrectione, non de ascensione. "“Ad orientem"

\footnotetext{
c For the doctrine that the void has no independent existence and therefore that movement through it is impossible, see Aristotle, Physics $4.8^{\prime}(214 \mathrm{~b} 12-216 \mathrm{a} 24)$.

d Ac 1: 10.

See n. 47 (p. 39 above).

f Ps 17: 11 .

Peter Lombard. Commentarium in Psalmos 17.12 (PL 191.190).

h Ps 67: 34.

i Lombard, Comm. 67.36 (PL 191.618).

j Ps 67: 5.

- Ps 67: 34.

1 Ps 67: 5.

m Lombard, Comm. 67.4 (PL 191.603).

$66 \mathrm{cn}$ (?) MS.

67 fort. quod legendum est.
} 
uel "ab oriente"; alia littera locum exprimit ubi resurrexit et unde ascendit, quia Ierusalem, ubi hec facta sunt', est in oriente. Uel ad orientem', id est, ut lumen gratie. nobis oriri faceret.'n Uel quia ascendit uerso uultu ad orientem - quodr néscio, licet uideatur Damascenus hoc dicere. ${ }^{\circ}$ Uel ad litteram quia terra promissionis est media habitabilis <zone> nostre - maxime lerusalem in medio quarti climatis sita tenet ${ }^{68}$ capitum. $^{\mathrm{p}}$ Ibi est medius punctus inter orientem habitabilis <zone> nostre et occidentem. Et quando sol transit per meridionalem circulum illum, necessario occidit sol existentibus in puncto orientali et oritur existentibus in puncto occidentali. Et ita cum directe ad illud tendit ${ }^{69}<\mathrm{et}^{\prime}>$ ascendit, ascendit ad órientem et occidentem.

\section{Fairfield University.}

$n$ ibid. (618).

- De fide orthodoxa 85.2. ed. Buytaert, pp. 305-306.

p For an example of the sort of geography which is framing Fishacre's thinking here. see 'Honorius of Autun. De imagine mundi 1.6 (PL 172.122-23).

68 tenit MS.

69 tenit MS. 


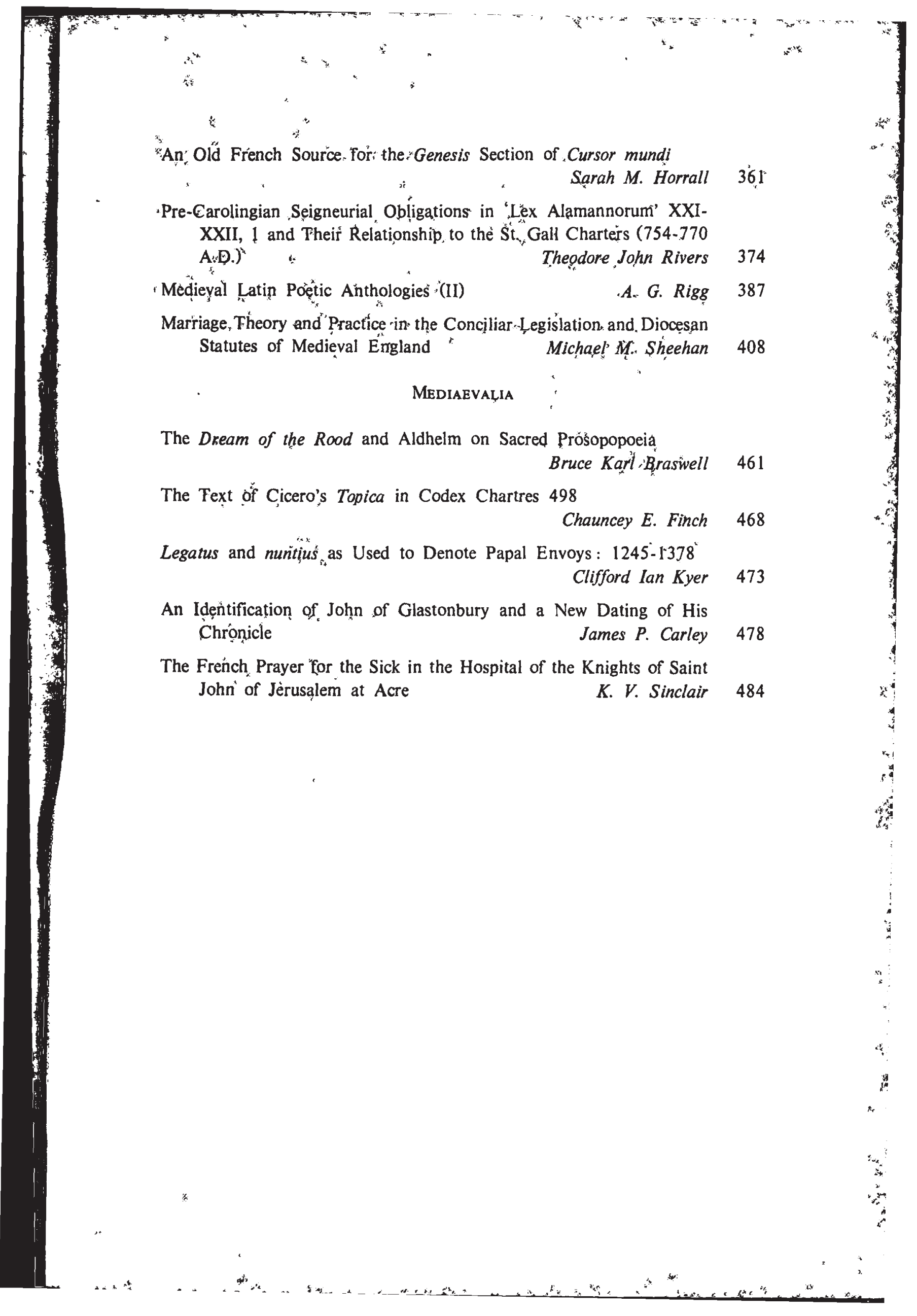

